
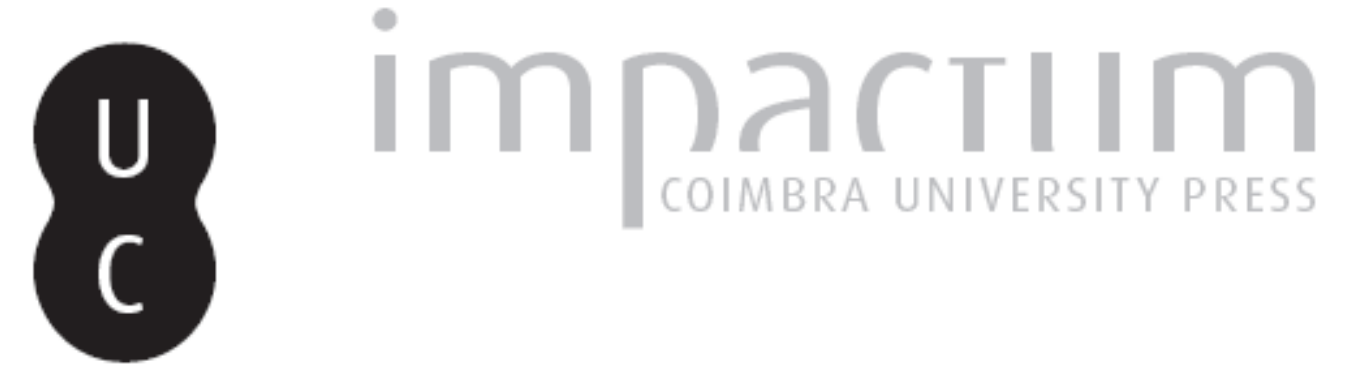

\title{
Enforced disappearance of persons under international criminal law: the case "Guerrilha do Araguaia" in Brazil
}

\author{
Autor(es): $\quad$ Pinto, Angela Pires
}

Publicado por: Universidade Católica de Petrópolis

URL persistente:

URI:http://hdl.handle.net/10316.2/33774

DOI:

DOI:http://dx.doi.org/10.14195/2175-0947_3-2_1

Accessed : $\quad$ 26-Apr-2023 13:02:43

A navegação consulta e descarregamento dos títulos inseridos nas Bibliotecas Digitais UC Digitalis, UC Pombalina e UC Impactum, pressupõem a aceitação plena e sem reservas dos Termos e Condições de Uso destas Bibliotecas Digitais, disponíveis em https://digitalis.uc.pt/pt-pt/termos.

Conforme exposto nos referidos Termos e Condições de Uso, o descarregamento de títulos de acesso restrito requer uma licença válida de autorização devendo o utilizador aceder ao(s) documento(s) a partir de um endereço de IP da instituição detentora da supramencionada licença.

Ao utilizador é apenas permitido o descarregamento para uso pessoal, pelo que o emprego do(s) título(s) descarregado(s) para outro fim, designadamente comercial, carece de autorização do respetivo autor ou editor da obra.

Na medida em que todas as obras da UC Digitalis se encontram protegidas pelo Código do Direito de Autor e Direitos Conexos e demais legislação aplicável, toda a cópia, parcial ou total, deste documento, nos casos em que é legalmente admitida, deverá conter ou fazer-se acompanhar por este aviso.

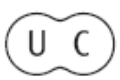



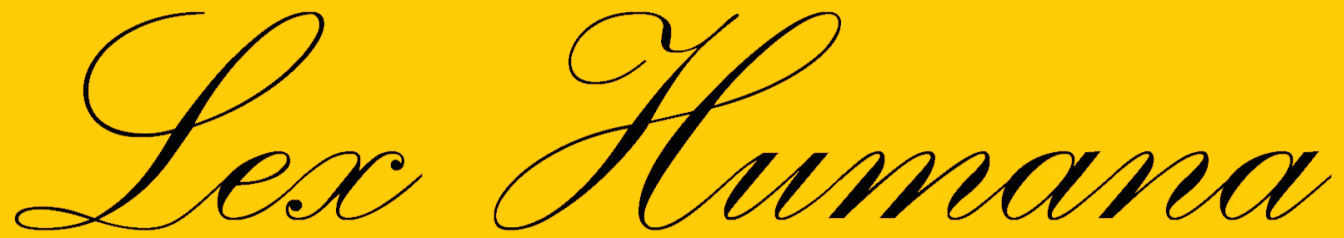

Revista do Programa de Pós-Graduação em Direito da UCP

ISSN(e) 2175-0947

Universidade Católica de Petrópolis Rua Benjamin Constant, 213 - Petrópolis - Centro CEP 25610-130

Tel: (24) 2244-4000 E-mail: lexhumana@ucp.br 


\section{ENFORCED DISAPPEARANCE OF PERSONS UNDER INTERNATIONAL CRIMINAL LAW: THE CASE “GUERRILHA DO ARAGUAIA" IN BRAZIL ${ }^{1}$}

Angela Pires Pinto ${ }^{2}$

Resumo: O caso "Guerrilha do Araguaia" é conhecido no Brasil pelos desaparecimentos forçados de opositores do regime militar no período entre 1972 e 1974 na região 'Araguaia'. Apesar dos esforços das famílias das vítimas visando responsabilização e reparação, pouco progresso foi feito. Em 1995, o Brasil reconheceu suas responsabilidades pelas mortes e criou uma Comissão para promover compensação às famílias das vítimas. A Lei de Anistia impediu que o Estado iniciasse os procedimentos criminais relacionados às responsabilidades dos envolvidos nos desaparecimentos, tortura e assassinatos. Em dezembro de 2010, a Corte Interamericana de Direitos Humanos decidiu que o Brasil é responsável pelos desaparecimentos forçados na regiáo do Araguaia e, seguindo sua jurisprudência anterior, determinou que o Estado iniciasse investigaçóes adequadas e procedimentos criminais relacionados aos fatos que representam crimes contra a humanidade. Visando a determinação das responsabilidades criminais no caso "Guerrilha do Araguaia", esse artigo examinará as bases da responsabilidade criminal dos supostos ofensores, a partir do direito internacional criminal assim como da legislação Brasileira, analisando as limitaçóes apresentadas por ambas jurisdiçóes.

Palavras-chave: Desaparecimento forçado; Direito Internacional Criminal; Anistia; Crimes contra a humanidade; Direitos Humanos.

Abstract: The case "Guerrilha do Araguaia" is well known in Brazil in the view of the disappearances of opponents to the military regime occurred between 1972 and 1974, in the region known as Araguaia. Despite the efforts made by the families of the victims to seek responsibility and redress, few progress has been done. In 1995, Brazil recognized its responsibilities for the deaths and established a Commission to provide compensation to the families of the victims. The Amnesty Law prevented the State to initiate the criminal proceedings related to the responsibilities of those involved in the disappearances, torture and killings. On December 2010, the Inter-American Court of Human Rights decided that Brazil is responsible for the enforced disappearances in the Araguaia's region and, following its previous jurisprudence, determined that the State initiate adequate investigation and criminal proceedings related to the facts that amount to crimes against the humanity. In the view of the

\footnotetext{
${ }^{1}$ Artigo recebido em 15/10/2011 e aprovado para publicação pelo Conselho Editorial em 04/11/2011.

${ }^{2}$ Mestranda em International Human Rights and Humanitarian Law da University of Essex, Inglaterra. Currículo Lattes: http://lattes.cnpq.br/0057560686629219. E-mail: angelapiresp@gmail.com.
} 
determination of criminal responsibilities on the "Guerrilha do Araguaia"'s case, this article will examine the grounds of criminal liability of the alleged offenders under the international criminal law as well as under the Brazilian domestic law, analysing the limitations that arise from both jurisdictions.

Keywords: Enforced disappearance; International Criminal Law; Amnesty; Crimes against the humanity; Human Rights.

\section{Introduction}

In 1964, after a coup d'etat, the Army took the power in Brazil and began a twenty years period of dictatorship. While enforcing several military missions to ensure national security $^{3}$, torture, enforced disappearances, unlawful arrests and other sorts of persecution against opponents were systematic practices ${ }^{4}$.

In 1966, a group of civilians, formed by members of the Communist Party, started to get organized to fight against the authoritarian regime. This group was based in the north of Brazil, in the Araguaia's riverbank. For this reason, the group and the incident that occurred in that place between 1972 and 1974 are known as "Guerrilha do Araguaia".

While in the first military operations the order was to identify the members of the "Guerrilha", from 1973, the orders were to "eliminate" those who were captured. By the end of 1974, the Guerrilha do Araguaia was extinct. The information suggests that their bodies were removed from the original places where they were initially buried, burned and threw into the river $^{5}$.

With the end of the dictatorship, a Catholic Church publication called "Brasil: Nunca Mais" ${ }^{3}$ reported hundreds of cases of torture, murderers and enforced disappearances occurred in the period. Furthermore, initiatives of victims' families and civil society

\footnotetext{
3 Studart, H. A Lei da Selva.1.ed. São Paulo: Geração Editorial(2006).P.129.

4 Brasil Nunca Mais (Petrópolis, Vozes, 1985).

5 Gomes Lund et al. ("Guerrilha do Araguaia”) v Brazil. Preliminary Objections, Merits, Reparations, and Costs. Judgment of November 24, 2010 (Only in Spanish) Series C No.219. Paras.89-90.

6 Supra.
} 
organisations to have access to information about all those detained and killed during military missions were strengthened.

Despite the efforts to seek responsibility and redress, few progress has been done. Search is still in place and a DNA database with information from the families was established. In 1995, Brazil recognized its responsibilities on the presumed deaths and established a Commission to provide compensation to the victims' families ${ }^{7}$. However, an Amnesty Law ${ }^{8}$ prevented the State to initiate the criminal proceedings related to those crimes.

On December 2010, the Inter-American Court of Human Rights (IACHR) decided that Brazil is responsible for the enforced disappearance of 62 persons in the mentioned period in Araguaia and, following its previous jurisprudence, determined that Brazil initiates adequate investigation and criminal proceedings related to the facts that amount to crimes against humanity ${ }^{9}$. In addition, the Court ruled that the Amnesty Law violates State's obligations under international law and shall not be applied.

In the view of the enforcement of the IACHR decision, this paper will determine how far the Brazilian obligations could be implemented regarding the investigations, trial and punishment of those involved in the enforced disappearances First, it will determine the elements of the crime of enforced disappearances as a crime against humanity. Then, it will examine the possibility of the prosecution of perpetrators. Finally, it will determine whether a civilian or a military court could offer sufficient redress as well as the role an international court could play.

\section{The enforced disappearances}

\footnotetext{
7 Law n. ${ }^{\circ}$ 9.140/95.Article 1. "It is acknowledged as deads, for all legal effects, people included on Attachment I(...), since they participated, or were accused to have participated, in political activities, during the period from 02 September 1961 to 15 August 1979, and that, for this reason, have been detained by public agents, remaining, since then, disappeared, without further notice about them". Free translation.

${ }^{8}$ The Federal Law n. ${ }^{\circ} 6.683 / 79$ provided amnesty for all those people who committed political crimes between 02 September 1961 to 15 August 1979. A Lawsuit demanded the non-applicability of the amnesty law to ordinary crimes committed against political opponents. On 29 April 2010, the Brazilian Supreme Court ruled in favour of the State (STF. Arguição de Descumprimento de Preceito Fundamental No.153).

9 Gomes Lund et al. Supra.
} 


\subsection{The definition and elements of the crime}

In 1992, the UN General Assembly adopted the Declaration on the Protection of All Persons from Enforced Disappearance ${ }^{10}$. The Declaration not only condemns any act of enforced disappearance, but requires that States treat them as offences under criminal law ${ }^{11}$. Later, other instruments were adopted under international law regarding enforced disappearances: the Inter-American Convention on Forced Disappearance of Persons (hereinafter referred to as the "Inter-American Convention") ${ }^{12}$, the Statute of the International Criminal Court, known as the Rome Statute ${ }^{13}$ and the International Convention for the Protection of All Persons from Enforced Disappearance (hereinafter referred to as the "International Convention") ${ }^{14}$. On International Humanitarian Law, some provisions also give rise to the prohibition of acts of enforced disappearances ${ }^{15}$.

The aforementioned instruments contain similar definitions on the enforced disappearance. Following the international jurisprudence ${ }^{16}$, the enforced disappearance is considered a plurioffensive crime, since it violates several human rights such as the right to liberty and security of person, the right to a fair trial and the right to life.

The constitutive element to determine a case of enforced disappearance, in addition to the detention or deprivation of liberty, is "the refusal to acknowledge the deprivation of liberty of the victim, or the concealment of his or her fate or whereabouts" ${ }^{17}$. Adding to the definition contained in the other instruments, the Rome Statute considers "the intention of removing the victim from the protection of the law for a prolonged period of time, as an

\footnotetext{
10 Adopted on 18 December 1992.GA Resolution 47/133.

11 Idem.Article 4.

12 Adopted at the $24^{\text {th }}$ Regular Session of the General Assembly to the Organization of American States. Entered into force in 28 March 2006.

13 A/CONF.183/9.Adopted in 1998. Article 7 defines enforced disappearances as a crime against the humanity. Further, in paragraph 2(i), it brings the definition of enforced disappearance.

14 General Assembly Resolution A/RES/61/177. Entered into force in December 2010. Brazil is party of this treaty.

15 See common Article 3 on 1949 Geneva Conventions and Article 4(2) of the Additional Protocol II,1977.

16 See for instance at IACHR: Velásquez Rodríguez v Honduras. Decision 29 July 1988, Para.155; Godínez Cruz v Honduras, Decision 20 January 1989, Para.157; Blake v Guatemala, Decision 24 January 1998, Bámaca Velásquez v Guatemala, Decision 25 November 2000.

17 A/HRC/16/48/Add.3 Para.28.
} 
element of the crime". ${ }^{18}$

Furthermore, acts of enforced disappearances are considered as a crime of continuous nature ${ }^{19}$. "The act begins at the time of the abduction and extends for the whole time that the crime is not complete, that is to say until the State acknowledges the detention or releases information pertaining to the fate or whereabouts of the individual" ${ }^{20}$. While the denial about the truth regarding the fate or whereabouts of the person is a key element of the crime, the crime of enforced disappearances remains in course until the deprivation ceases or it is not denied any more and the fate or whereabouts are clarified.

The acknowledgement of the nature of acts of enforced disappearances as a continuous crime gives rise to the jurisdiction of competent bodies to consider State's responsibilities under an instrument which entered into force after the enforced disappearance began. In addition, "the State should be held responsible for all violations that result from the enforced disappearance, and not only for violations that occurred after the entry into force of the instrument."21

In Guerrilha do Araguaia v Brazil, upon the State's argument that the facts occurred before the State's acceptance of the Court's jurisdiction on 1998, the IACHR recalled the nature of continuous crime of enforced disappearances and found the case admissible. However, since the body of one of the victims was identified on 1996, before the acceptance of the Court's jurisdiction, the Court was not competent to pronounce any decision related to the enforced disappearance of this victim ${ }^{22}$.

\subsection{The enforced disappearance as a crime against the humanity}

As defined by international law instruments, acts of enforced disappearance are

\footnotetext{
$18 \mathrm{~A} / \mathrm{HRC} / 7 / 2$, para.26.

19 For information on countries practice, see A/HRC/16/48/Add.3 Para.34.

20 General comment on enforced disappearance as a continuous crime. In:A/HRC/16/48.

21 Idem.Para.3-4.

22 Gomes Lund et al. Supra.Paras.13-19.
} 
acknowledged as crimes against humanity ${ }^{23}$. As a crime against humanity, it shares in this category a set of common features:

1.They are particularly odious offences in that they constitute a serious attack on human dignity or a grave humiliation or degradation of one or more persons; 2 .They (...) are part of a widespread or systematic practice of atrocities that either form part of a governmental policy or are tolerated(...) by a government(...); 3. They are prohibited and may consequently be punished regardless of whether they are perpetrated in time of war or peace.(...); 4.The victims of the crime may be civilians or, where crimes are committed during armed conflict, persons who do not take part (or no longer take part) in armed hostilities(... $)^{24}$.

Regarding its subjective elements, to be aware of the risk about the actions that will be taken (dolus eventualis) may be sufficient to fill the intent (mens rea) ${ }^{25}$. However, in crimes against humanity, the subjective element is not limited to the criminal intent, the agent must "be cognisant of the link between his misconduct and a widespread or systematic practice" ${ }^{26}$. When crimes against the humanity amount to persecution, it also requires a special criminal intent (dolus specialis): a persecutory or discriminatory animus against a person or group based on their religious, political or other grounds ${ }^{27}$.

One of the consequences of the recognition of certain acts as crimes against humanity concerns to prescription. On the implementation of the Rome Statute, no statute of limitations is applicable28. In this regard, international and national courts have been consistent on affirming that crimes against humanity are imprescriptible. In Barrios Altos, for instance, the IACHR stated that "are inadmissible[...] any prescription measure[...] that intends to prevent the investigation and punishment of those who are responsible for grave human rights violations such as torture, summary executions and enforced disappearances, all

23 Rome Statute. Article 7(1)(i); Inter-American Convention, preamble, para.6; International Convention, preamble, para.6.

Cassesse,A. International Criminal Law. (Oxford, 2003) P.99.

25 Idem.P.114.

26 Idem.

27 Idem.P.115.

28 Article 29. 
of them prohibited since they contradict underogable rights ${ }^{29}$. Therefore, people who commit crimes against humanity should always be criminally prosecuted. Nothing should prevent it, including prescription, pardon or any amnesty law ${ }^{30}$. In Simón, Julio Héctor and others, as on later cases, ${ }^{31}$ the Supreme Court of Argentina, considering the amnesty law "null and void", ruled the "opening or re-opening of judgments over the crimes committed by the military in the Seventies, including thousands of cases of enforced disappearances"32.

In the case of "Guerrilha do Araguaia", the IACHR recalled the imprescriptibility of the crimes against humanity ${ }^{33}$ and the inapplicability of the amnesty law to rule the State's responsibility to investigate, trial and sanction the perpetrators.

\section{Prosecuting perpetrators of enforced disappearances}

While addressing human rights violations perpetrated in the past, States can have several objectives: to punish the perpetrators, to establish the truth, to promote reparations, to promote reconciliation and to prevent other violations in the future. States can hold trials, prosecution, purge perpetrators from public functions, establish commissions to investigate the facts, promote access to security files, compensate the victims, build memorials and promote institutional reforms $s^{34}$.

Considering that torture and enforced disappearances against political opponents were common practices in many countries, while silence and impunity have been for a long time general rule ${ }^{35}$, many countries have made progress on uncovering the truth and promoting redress. Following the international community concerns, several countries

\footnotetext{
29 Decision 14 March 2001. Para.41.

30 Nino,C. Juicio al mal absoluto (Errecé. Buenos Aires, 1997).P.25.

31 Supreme Court of Justice, Case S.1767.XXXVIII, Simón, Julio Héctor y otros s/ privación ilegítima de la libertad, etc., judgment of 14 June 2005.

32 A/HRC/16/48/Add.3 Para.37 see footnote 57.

33 Gomes-Lund et al.Supra. Also Opinion judge ad hoc Roberto de Figueiredo Caldas. Para.27.

${ }^{34}$ Hayer, P. Enfrentando crímenes pasados y la relevância de comisiones de la verdad. In: Ensayos sobre la justicia transicional. Centro Internacional para la Justicia Transicional. P.118-119.

35 Gallego, J. La Desaparicion Forzada de Personas en el Derecho Internacional de los Derechos Humanos(Buenos Aires, Adhoc, 2007).P.40; 47.
} 
established Truth Commissions, recognized the ineffectiveness of the amnesty laws and promoted criminal proceedings against perpetrators.

Raul Alfonsin ${ }^{36}$, President of Argentina during the transition, recalls three alternatives for his country in that time. The first one was to forget (through an amnesty law or inaction) and it was not a valid alternative for them. Second was to prosecute all perpetrators that could be accused, but never before a country have done that. In this case, not only the political moment should be considered but there were also legal and factual concerns. The third alternative was to punish the main perpetrators regarding their responsibility in command and that is how the country proceeded.

In the process of promoting criminal proceedings, considering the nature and the period when the crimes were committed, some concerns arise regarding who should be prosecuted and the evidence available to promote their responsabilization.

\subsection{Individual criminal responsibility}

In view of holding perpetrators of acts of enforced disappearances into account, it is necessary to determine whether it is reasonable to prosecute all those involved in the crimes or if it would be preferable to prosecute the main agents, considering their responsibilities in command of operations.

The International Convention in article 6, paragraph 1, encourages States to:

take the necessary measures to hold criminally responsible at least: a) any person who commits, orders, solicits or induces the commission of, attempts to commit, is an accomplice to or participates in an enforced disappearance; b) a superior who: (i) knew, or consciously disregarded information which clearly indicated, that subordinates under his or her effective authority and control were committing or about to commit a crime of enforced disappearance; (ii) exercised effective responsibility for and control over activities which were concerned with the crime of enforced disappearance; and (iii) failed to take all necessary and reasonable measures within his or her power to prevent or repress the commission of an enforced disappearance or to submit the matter to the competent authorities for

\footnotetext{
36 Nino,C. Supra.P.10.
} 
investigation or prosecution".

Article 6 of the International Convention also states the inapplicability of the principle of hierarchic obedience. Articles 25 and 28 of the Rome Statute bring similar criteria.

According to the theory of "command responsibility", someone from superior hierarchy can be held responsible for the acts of her/his subordinates if s/he knew or had reason to know and did not take the necessary measures to prevent them to commit those acts or to punish them ${ }^{37}$.

In Argentina, on December 1985, the Federal Criminal Court decided to focus on 709 from 7.380 reported cases against the armed forces commanders. The Court decided to focus on those agents who had the power to control the course of the events. In addition, the Court started from the point that, considering the pattern of the operations and control over the armed forces, the commanders knew the procedures that were used by their subordinates, including the practice of torture, kidnapping and murder ${ }^{38}$. Because it was a very complex process, it was not an option to pursue trials in regard of thousands of Armed Forces members. The aim was an exemplary punishment to ensure the non-repetition of the facts ${ }^{39}$.

In South Africa, in 1999, the Truth and Reconciliation Commission forwarded 300 cases for criminal investigation. However, recognizing its lack of resources and capacity to investigate, it brought a list representing " 'those names that came up constantly' in its investigations". Unfortunately, they found that only 21 cases were "worthy of investigation" and, finally, no one from the list was prosecuted, mainly due to amnesties, causing anger and frustration ${ }^{40}$.

For the approval of the Law 9.140/95, Brazil recognized that its public officers committed a crime of the most serious gravity:"It was characterized, then, an illicit of

\footnotetext{
37 Ratner, S. et all. Accountability for human rights atrocities: beyond the Nuremberg legacy. (Oxford: Oxford University Press, 2009). P.146-148.

38 Gallego,J. Supra.P.41-42.

39 Nino,C. Supra.P.21.

40 Hayner,P.(2011) P.101-102.
} 
maximum gravity committed by public agents or agents undertaking public functions: they should have taken care of those who were under their responsibility and they didn't" ${ }^{41}$. Therefore, in the exam of who to prosecute, following the international framework, Brazil should consider the role its agents played, including the command of operations and compliance with those acts. It should also be borne in mind that most of senior officers in command are no longer alive.

\subsection{Providing evidence}

One particularity of this crime is the active participation of State agents, including those who are in charge of investigating the crimes. For this reason, the truth sometimes remains covered by the fact that it is hard to obtain any documental proof of the acts committed $^{42}$. Regarding the collection of evidence, the IACHR has expressed that any trace and indirect testimonies about the facts should be considered, since one of the characteristics of this crime is to abolish all elements that could make proof of the facts ${ }^{43}$.

In this view, it should be stressed that obligations to punish the perpetrators of enforced disappearances flow from the right to the truth ${ }^{44}$. Truth should be uncovered to clarify cases and to ensure non-repetition of similar acts ${ }^{45}$. Furthermore, "the right to the truth implies that the State has an obligation to give full access to information available, allowing the tracing of disappeared persons" ${ }^{36}$.

Although the obligation to investigate exists, it could be borne in mind that in certain circumstances clarification is difficult to be achieved. In Uganda, the Truth Commission (1986-1996) forwarded about 200 cases for further investigation, indicating that all those implicated should be prosecuted. However, from 1991 to 1995 only one to three cases went to the Prosecutor's Office, mainly because of the lack of evidence, since witnesses feared

\footnotetext{
41 Explanation of reasons $n .^{\circ} \mathrm{MJ} / 352$, regarding the Law $n .{ }^{\circ} 9.140 / 95$.

42 Gallego,J.Supra. P.54.

43 Velásquez-Rodríguez Para.131; Godinez Cruz. Para.137.

44 See article 24 of the International Convention.

45 General comment on the right to the truth in relation to enforced disappearance. In: A/HRC/16/48.

46 Idem.Para.9.
} 
testifying ${ }^{47}$.

In 1995, the Brazilian government recognized that 136 people were to be considered dead in regard of their participation on political activities from 02 September 1961 to 15 August $1979^{48}$. However, the circumstances of these deaths and disappearances remained unacknowledged. A special commission was established to identify all those people considered disappeared and provide reparation to their families. The procedures required from the families to prove the facts. It caused outrage from the families, who were at the same time asking information from the government regarding the facts ${ }^{49}$. Not only the information regarding those who died fighting for the Guerrilha was denied but also the information about those who fought against $\mathrm{it}^{50}$.

A Lawsuit ${ }^{51}$ initiated in 1982 by the victims' families demanded from the State information about the people disappeared, including their fate or whereabouts, mortal remains and circumstances of their death. After a final decision against the State in 2008, some documents were made available on July 2009. Another Lawsuit ${ }^{52}$ requiring the release of information about the military operations in Araguaia was decided against the State, however, still waits a final decision. The information regarding the facts still remain on secrecy and incidents concerning destruction of evidence were reported during the period.

In 2003, the Court of Justice also determined that the Brazilian State indicate where the bodies were buried, provide information to issue the death certificates as well as other information regarding the investigation of the facts ${ }^{53}$. On 1996, the Brazilian government initiated the search for the bodies of those who were considered to be disappeared during the "Guerrilha do Araguaia". Until April 2011, only three people were found and identified ${ }^{54}$.

In "Guerrilha do Araguaia v Brazil", IACHR ruled that Brazil should: 1)initiate the

\footnotetext{
47 Hayner, P.(2011) P.97-98.

48 Law $9.140 / 95$.

49 Grupo Tortura Nunca Mais. Algumas reflexões sobre a Medida Provisória 2.151/01.

50 Studart,H.Supra.P.50.

51 Case nº820024682-5; 1ª Vara Federal; 19 February 1982.

52 Açao Civil Pública No.2001.39.01.000810-5.

53 Case no820024682-5.Supra.

54 Maria Lúcia Petit da Silva(1996), Lourival Moura Paulino(2008) and Bérgson Gurjāo Farias(2009).
} 
investigations related the enforced disappearances, taking into consideration the pattern of human rights violations during the period of ditactorship; 2)determine who are the authors (material and intellectual) of the crimes, considering the nature of continuous and permanent crime of the acts of enforced disappearances and the non-application of any statute of limitation; 3)ensure that the competent authorities have access to all necessary information regarding the facts and that any authority should refrain from raising obstacles towards procedures $^{55}$.

\section{Jurisdiction}

The implementation of the Rome Statute in domestic legislations, specially articles 25 and 28 , has provided the basis to promote individual responsibility ${ }^{56}$. The International convention's articles also have the same capacity. In this regard, to bring a case to justice gives rise to determine which court would have jurisdiction over the cases. It is also relevant to discuss whether it would be sufficient the establishment of a military court to hold the investigations and trials concerning the enforced disappearances committed by State's armed forces.

In Argentina, while right-wing sectors believed that any policy to review the past was an attack to the Armed Forces, human rights movements required the appearance with life of all those disappeared and punishment to all those who were responsible. There were also those who believed that those punishments could generate an atmosphere of tension in the Armed Forces and give rise to a new coup $d^{\prime}$ etat. To solve this tension, it was decided to count with the participation of the Armed Forces Surpreme Council. The military tribunal would intervene in first instance but the last resort would be the Federal Court, which could also intervene in case of denial or delay of justice ${ }^{57}$. With the Supreme Council denial to judge the cases, it was the "first time on history that the trials of top perpetrators were entrusted to the

\footnotetext{
55 Para.256.

56 A/HRC/16/48/Add.3 Para.37 see footnote 34.

57 Nino,C.Supra.P.12-14.
} 
Federal Courts, nullifying a corporative tradition of militaries being tried by their own comrades" 58 .

In the Araguaia's case, the Armed Forces speech says that the military officers just reacted to the "Guerrilha", in a context where the question was "to kill or to die" ${ }^{59}$. It should be noted that although sometimes the Armed Forces want to justify those actions, implying that there was a "state of war" and, therefore, everything is admissible, including torture and enforced disappearances, even if the situation was considered an "armed conflict" $"$, this perception would not be accepted by international humanitarian law ${ }^{61}$.

In Brazil, the military justice has jurisdiction over crimes committed by military officers in their activities ${ }^{62}$, however, any investigation was not initiated under this system. In 1996, a law reform introduced into the Military Criminal Code that if a crime against a civilian's life is committed with dolus, the ordinary justice has jurisdiction over it ${ }^{63}$. In case of conflict between civil and military justice, the Supreme Court has jurisdiction to decide about $\mathrm{it}^{64}$. In addition, article 109 of the Brazilian Constitution also stipulates that, regarding crimes committed by public officers under the command of federal forces, such as the Armed Forces, the Federal Justice has jurisdiction over the case.

In addition, it is necessary to consider the possibilities to bring perpetrators to trial. One question that arises is whether military officers can be prosecuted by civil courts for acts committed during military missions. Considering article 16, paragraph 2 of the Declaration, those responsible for acts of enforced disappearances "shall be tried only by the competent ordinary courts, in each State, and not by any other special tribunal, in particular military courts". Similar provision can be found in article 9 of the Inter-American Convention.

For instance, in Peru, the Truth and Reconciliation Commission prepared cases for

58 Idem.P.14. Free translation.

59 Studart,H.Supra.P.115.

60 The "Guerrilha do Araguaia" was not regarded as an "armed group",according to the definitions under international humanitarian law since, although its 70 members had to obey to a general command, they did not have the domain of any territory.

61 The four 1949 Geneva Conventions and its two 1977 Protocols, between other instruments, provide the legal basis for the prohibition of torture, unlawful arrests and killings.

62 Military Criminal Code. Decree n.1001/69. Art.9.

63 Law no9.299/1996.

64 Military Criminal Proceedings Code. Decree n.1002/69. Art.121. 
prosecution, leading to the establishment, in 2005, of a new National Criminal Court where, until 2008, 15 cases of forced disappearances were tried, involving 64 accused, 12 were convicted. However, this Court had some difficulties on accepting the facts as crimes against the humanity as well as the idea of "command responsibility" ${ }^{\circ}$.

On 04 April 2011, Brazil ratified the International Convention on Enforced Disappearances and, in the opposite of some countries ${ }^{66}$, has not already incorporated the crime of enforced disappearance into its domestic legislation. However, the absence of an autonomous crime does not excuse States from investigating and punishing acts of enforced disappearances ${ }^{67}$. National legislation provides safeguards from various offences that are linked with enforced disappearance, such as kidnapping and illegal deprivation of liberty, abuse of power and homicide ${ }^{68}$.

Under the lack of specific provision in the domestic law, the enforced disappearances could be understood as the crime of "kidnapping", Article $148^{69}$ of the Brazilian Penal Code. As well as the typology of enforced disappearance, it is also considered a continuous crime. Therefore, since the whereabouts of the victims are still unknown, the crime is still in place. Acknowledging that the criminal activity began in 1972 and did not ceased, the statute of prescription cannot be applied.

\section{The role of an international tribunal}

Although it is the primary responsibility of national authorities to bring perpetrators to trial, when it fails or it is not politically viable, the international community can intervene. As a complementary procedure, for instance, the International Criminal Court (ICC) has

\footnotetext{
65 Hayner,P.(2011) P.95-96.

${ }^{66}$ For instance, Argentina, Colombia, El Salvador, Guatemala, Mexico, Paraguay, Peru, Uruguay and Venezuela recognized the enforced disappearance as a specific crime. Brazil has not yet incorporated the crime of enforced disappearance into its domestic legislation.

67 A/HRC/16/48/Add.3. Para.10.

${ }_{68}$ Brazilian Penal Code. Decree n. 2.848/40.

69 Article 148 defines the crime of kidnapping as depriving someone of his/her freedom through kidnapping or false imprisonment, and counts with aggravating circumstances regarding the length of time and consequences to the integrity of the victim.
} 
jurisdiction to hold to trial perpetrators of the most serious crimes of concern to the international community, including crimes against humanity ${ }^{70}$. Then, "if the domestic authorities are either unwilling or unable to prosecute, or if national proceedings are not deemed to be "genuine", then the ICC prosecutor could act"71.

In addition, "Even if it cannot lead to invoking the jurisdiction of the International Criminal Court, an isolated act of enforced disappearance nonetheless remains an international crime and a gross human rights violation, which determines the criminal responsibility of the perpetrators, as required by several international human rights treaties"72.

The ICC as other ad hoc tribunals, such as the International Criminal Tribunal for the former Yugoslavia(ICTY) and International Criminal Tribunal for Rwanda(ICTR), have been important actors to prosecute perpetrators of crimes against humanity. Recently, ICC is holding six senior politicians and government officials in trial for crimes against humanity perpetrated during Kenya's 2007 general election. In all the cases, the cooperation of States is essential to the effectiveness of judicial process.

\section{Conclusions}

How a Nation confront its past has an important impact in its future. For this reason, to confront a legacy of human rights violations, the human rights framework, the international experience as well as the related historical circumstances should be considered ${ }^{73}$. With the end of dictatorship in Brazil, a new Constitution entered into force, affirming the prevalence of human rights, condemned the practice of torture and arbitrary detention as well as affirming the right to have access to information. In addition, Brazil started to ratify most of international human rights treaties.

However, applying an Amnesty Law, Brazil failed to hold trials and sanctions to

\footnotetext{
70 Rome Statute. Preamble and article 5.

71 Hayner,P.(2011) P.113.

72 A/HRC/16/48/Add.3 Para.18.

73 Zalaquett,J. La reconstrucción de la unidad nacional y el legado de violaciones de los derechos humanos. In: Revista Perspectivas, Facultad de Ciencias Físicas y Matemáticas,Universidad de Chile, Vol.2,Número Especial. Santiago de Chile(1999).
} 
perpetrators of enforced disappearances and other crimes committed during the dictatorship. In the Case "Guerrilha do Araguaia", the facts remain uncovered. The access to information and justice has been limited by the State and, consequently, perpetrators also remain unpunished.

To comply with their obligations, States must investigate the facts and bring the perpetrators to justice as well as promote the necessary legal and institutional reforms to make it possible. Although there is the possibility of perpetrators to be held into account by the Brazilian Criminal System, difficulties concerning the collection of evidence and the jurisdiction over the cases arise. Other countries experiences show that, to move towards the punishment of perpetrators of crimes against humanity, it is necessary to have a strong political will to do so. 


\section{Bibliography}

BRASIL NUNCA MAIS. Petrópolis, Vozes, 1985.

BRASIL. Secretaria Especial dos Direitos Humanos. Comissão Especial sobre Mortos e Desaparecidos Políticos. Direito à verdade e à memória: Comissão Especial sobre Mortos e Desaparecidos Políticos / Comissão Especial sobre Mortos e Desaparecidos Políticos - Brasília : Secretaria Especial dos Direitos Humanos, 2007.

CASSESE, A. International Criminal Law. Oxford, 2003.

FELIPE, G. A Guerrilha do Araguaia (Brasil: 1966 - 1975 ). D.E.A. Thesis. Institut des Hautes Études de l'Amérique Latine (I.H.E.A.L.), Université de la Sorbonne Nouvelle, (Paris III), October 1993.

GALlEGO, J. La Desaparicion Forzada de Personas en el Derecho Internacional de los Derechos Humanos. Buenos Aires, Ad-hoc, 2007.

GRUPO TORTURA NUNCA MAIS. Algumas reflexóes sobre a Medida Provisória 2.151/01. HAYER, P. Unspeakable truths. Transitional Justice and the Challenge of Truth Commissions. Second edition. Routledge. 2011.

. Enfrentando crímenes pasados y la relevância de comisiones de la verdad. In: Ensayos sobre la justicia transicional. Centro Internacional para la Justicia Transicional.

NINO, C. Juicio al mal absoluto. Errecé. Buenos Aires, 1997.

RATNER, S. et all. Accountability for human rights atrocities: beyond the Nuremberg legacy. Oxford: Oxford University Press, 2009.

STUDART, H. A Lei da Selva. 1. ed. São Paulo: Geração Editorial, 2006.

UN. Report by the Human Rights Council Advisory Committee on the Working Group on Enforced or Involuntary Disappearances. A/HRC/16/70/48. Available at: http://www2.ohchr.org/english/bodies/hrcouncil/docs/16session/A.HRC.16.48 en.pdf

UN. Report by the Human Rights Council Advisory Committee on the Working Group on Enforced or Involuntary Disappearances. Addendum. Best practices in the matter of 
missing persons. A/HRC/16/48/Add.3. Available at: http://www2.ohchr.org/english/bodies/hrcouncil/docs/16session/A-HRC-16-48-Add3.pdf ZALAQUETT, J. La reconstrucción de la unidad nacional y el legado de violaciones de los derechos humanos. In: Revista Perspectivas, Facultad de Ciencias Físicas y Matemáticas, Universidad de Chile, Vol. 2, Número Especial. Santiago de Chile, 1999.

\section{$\underline{\text { Statutes }}$}

International System

Declaration on the Protection of All Persons from Enforced Disappearances, General Assembly Resolution 47/133, 47 UN GAOR Supp. (No. 49) at 207, U.N. Doc. A/47/49 (1992). Adopted by General Assembly resolution 47/133 of 18 December 1992.

International Convention for the Protection of all Persons from Enforced Disappearance (2006). General Assembly Resolution A/RES/61/177.

Statute for the International Criminal Court. Rome Statute. A/CONF.183/9. Adopted in 1998.

Inter-American System

Inter-American Convention on Forced Disappearance of Persons. Adopted at the $24^{\text {th }}$ Regular Session of the General Assembly to the Organization of American States. Entered into force in 28 March 2006.

Brazil

Brazilian Penal Code. Decree n. ${ }^{\circ} 2.848 / 40$

Military Criminal Code. Decree n.1001/69.

Military Criminal Proceedings Code. Decree n.1002/69.

\section{$\underline{\text { Case Law }}$}




\section{Inter-American Court of Human Rights}

Bámaca Velásquez v Guatemala, Decision 25 November 2000.

Blake v Guatemala, Decision 24 January 1998

Godínez Cruz v Honduras, Decision 20 January 1989

Gomes-Lund et al. (Guerrilha do Araguaia) v. Brazil. Preliminary Objections, Merits, Reparations, and Costs. Judgment of November 24, 2010 (Only in Spanish) Series C No. 219. Opinion Judge Figueiredo-Caldas (Only in portuguese) .

Ibsen-Cárdenas and Ibsen-Peña v. Bolivia. Merits, Reparations and Costs. Judgment of September 1, 2010. (Only in Spanish) Series C No. 217.

Velásquez-Rodríguez v. Honduras. Merits. Judgment of July 29, 1988. Series C No. 4.

Rosendo-Cantú and other v. Mexico. Preliminary Objection, Merits, Reparations, and Costs. Judgment of August 31, 2010. Series C No. 216

\section{Argentina}

Supreme Court of Justice, Case S.1767.XXXVIII, Simón, Julio Héctor y otros s/ privación ilegítima de la libertad, etc., judgment of 14 June 2005.

\section{Brazil}

Açao Civil Pública No. 2001.39.01.000810-5.

STF.Arguição de Descumprimento de Preceito Fundamental No.153.

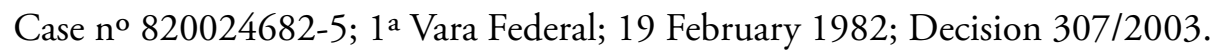

